\title{
Or^ran, ^eкuï
}

УДК 613.6: 662.756:63:001.5

\section{ГIГIEHIЧHI ACПЕКТИ ВИРОБНИUТВА БIOПАМИвА I РОСАИННОї

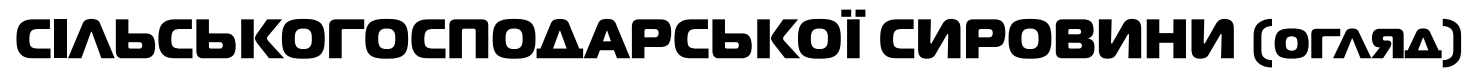

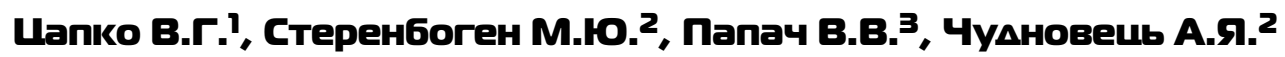 \\ 'Нашіональний аграрний університет, м. Київ \\ ${ }^{2} \Delta У$ «Інститут меАичини праші АМН України», М. Київ \\ ӞОбласна СЕС, м. Черкаси
}

Представлено дані аналізу літератури та результати дослідження умов праці при виробництві біопалива із рослинної сільськогосподарської сировини на різних технологічних етапах. Надано характеристику технологічних та гігієнічних особливостей виробництва біопалива.

Ключові слова: технології виробництва, біопаливо, умови праці

\section{Вступ}

Широкого розповсюдження у світі, в тому числі на Україні, набуває виробництво енергетичних польових культур. Відбувається поступово заміщення традиційних енергетичних ресурсів відповідними аналогами рослинного походження. Для України розвиток альтернативної енергетики у сільській місцевості становить один із важливих державних пріоритетів, що базуються на широкому впровадженні новітніх технологій, машин та обладнання. Основні шляхи розвитку виробництва рідкого біопалива, призначеного для транспортних засобів із дизельними двигунами та двигунами внутрішнього згоряння, безпосередньо пов'язані $з$ вирощуванням олійних культур і рослин з великим вмістом крохмалю [2, 3]. По оцінкам спеціалістів найбільш перспективною сільськогосподарською культурою в цьому аспекті є ріпак, з якого виробляють основні компоненти біодизельного палива. Крім того, врожай ріпаку, отриманий з 1 га площі при відповідній технології вирощування дає 20 т зелених кормів, 20 т зелених добрив, 3-3,5 т насіння, 13 ц олії, 16 ц макухи (шроту), 100 кг меду, 500 кг паперу.

Зважаючи на досвід європейських держав, виробництво біодизеля в Україні можна організувати на малотоннажних установках, потужністю 3003000 т/рік (для фермерів), регіональних (обласні) заводах (10000-30000 т/рік), промислових заводах державного значення (50000-100000 т/рік). Відповідно до «Програми розвитку виробництва біодизельного палива за період до 2010 р.» Україна повинна виробляти й споживати в 2010 р. більше 520 тис. т біодизельного палива, що передбачає забезпечити валовий збір насіння ріпака близько 1,7-1,8 млн т.
Біодизельне паливо (біодизель) - це екологічно чистий вид біопалива, що виробляється з жирів рослинного та тваринного походження й використовується для заміни нафтового дизельного палива. За хімічним складом, біодизель $є$ сумішшю метилових (етилових) ефірів, насичених і ненасичених жирних кислот. Під час реакції переетерифікації олії жири вступають у реакцію з метиловим (етиловим) спиртом у присутності каталізатора (лугу), внаслідок чого утворюються складні ефіри, а також гліцеролова фаза: 56 \% гліцерину, 4 \% метанолу, $13 \%$ жирних кислот, 8 \% води, $9 \%$ неорганічних солей, 10 \% ефірів. Біодизель може використовуватися в будь-яких дизельних двигунах без внесення зміни в конструкцію двигуна [4].

Однією із переваг застосування біодизеля $є$ також його екологічна чистота.

У природних умовах біодизель та мастила з ріпака піддаються швидкому біологічному розщепленню та знешкоджуються мікроорганізмами впродовж 7-8 днів на $95 \%$, в той час як звичайні нафтопродукти тільки на 16 \%. Біодизель - це акумульована сонячна енергія. Порівняно зі звичайним дизелем він має ту перевагу, що завдяки високій частці ріпакової олії при його згорянні виділяється тільки така кількість $\mathrm{CO}_{2}$, яку рослини взяли з атмосфери, що практично не впливає на довкілля $[5,6]$.

При роботі двигунів на біодизелі значно зменшуються шкідливі викиди інших продуктів згоряння, в тому числі сірки - на 98 \%, а сажі - від 50 до $61 \%$, гідрокарбонатів - та вуглекислих монооксидів - на 30-34\%. При використанні 100 т біодизеля викиди в атмосферу вуглекислого газу зменшуються на 78,5 т. порівняно з використанням нафтового пального. В процесі вирощування ріпак здатен очищувати поля від радіонуклідів, не нагромаджуючи їх у насінні. Отже, ріпак можна впроваджувати для ре- 
культивації забруднених земель, використовуючи насіння для одержання біодизеля.

Повний технологічний процес отримання біодизельного палива включає умовно наступні етапи:

- вирощування та збирання врожаю;

- приймання та зберігання сировини в операційних резервуарах необхідної місткості;

- переробку сировини (пресування насіння на лінії вижимки, фільтрування (очистки) і нейтралізацію олії, iï зберігання та подачу до ділянки етерифікації;

- виробництво біодизельного палива з олії на лінії етерифікації,

- зберігання готової продукції та її відправку спо живачам.

На етапі переробки здійснюють приймання сировини, іiї зберігання в резервуарах та подачу до ділянки пресування. При біодизельному виробництві очищене і висушене насіння ріпака зберігають в технологічному сховищі, розміщеному поруч з олійницею. Насіння ріпака різних сортів, призначене для виробництва олії, повинне мати вологість $5-7$ \%, засміченість- не більше $1 \%$, вміст ерукової кислоти - менше $2 \%$ та кислотне число - не більше 3. Порушення цих вимог погіршуе ефективність вижимання та етерифікації, а також може стати причиною зниження якості олії. На це впливають, зокрема, ступінь стиглості насіння та умови його зберігання.

На другому етапі переробки насіння для вижимки беруть з резервуару і подають до обладнання попередньої підготовки, де його звільняють від сторонніх предметів, домішок, пилу, тощо. Потім насіння дозовано подають в шнековий прес, де відбувається процес вижимки олії. Олію з насіння ріпака вижимають пресами 3 продуктивністю від 200 кг/год до 100 т/год в залежності від масштабу виробництва. Преси, звичайно шнекові, одно - або багатосекційні, можуть бути обладнані попередніми камерами, де насіння підігрівається, що поліпшує процес віджимання олії. Приблизно 40-44\% насіння ріпака в сухій масі складають жири, а після одноразової вижимки в жомі залишається до 10-12 \% жиру. Описаний процес вижимки називається холодною вижимкою, оскільки температура олії не перевищує 50-60 С. Для такої вижимки застосовують спеціальні преси. Вони входять до складу ліній 3 виробництва рослинної олії. Одержана олія стікає в резервуар, а звідти подається у фільтраційні установки, де відбувається відділення твердих частинок. Далі олія підлягає подальшому очищенню 3 осадженням фосфорних сполук, а вільні жирні кислоти нейтралізуються і вимиваються. Потім олію зневоднюють і зберігають у резервуарі для чистої олії.
На підприємствах олійної промисловості після першого вижимання (насіння може бути попередньо підігріте і подрібнене) вижимки перемішують в екстракційній камері з розчинниками (бензин, гексан), щоб розчинити ту частина жирів, що залишилася. Цю суміш підігрівають, а пари розчинників конденсують і повторно використовують. У результаті процесу екстрагування в шроті залишається лише 1-2 \% жирів. Олія, отримана в процесі екстракції, звичайно перемішується з олією, одержаною після першої вижимки, у пропорції 2:1. Екстракційна олія, як правило, забруднена, оскільки розчинники екстрагують олію разом з великою кількістю токсичних речовин. Застосування розчинників викликає їх емісію у навколишнє середовище у кількості 2-4 кг на одну тонну насіння ріпака, що у декілька разів перевищує європейські норми.

На противагу екстракції,холодна вижимка олії є повністю нейтральним методом для навколишнього середовища, а шрот після холодного вижимання $€$ кормом для всіх видів тварин (з відповідними пропорціями у кормових сумішах). Шрот, що утворюеться в результаті пресування насіння, вміщуе жири (8$12 \%$ ) і білки (30-32 \%). Він випадає зі шнекового пресу у вигляді пластин, його транспортують в дробарку для подрібнення на маленькі частинки однакового розміру. У такій формі шрот подають у змішувач, куди також відправляють всі відходи, що виникають в процесі фільтрації та рафінування олії. Перемелені вижимки, які мають високу температуру, спрямовують в охолоджувач. Потім їх транспортують у сховище і там зберігають до відправки споживачу або на комбікормові заводи для подальшої переробки. Ріпаковий шрот можна далі переробляти в комбікорм.

Шрот є цінним кормом для риб та хутрових звірів. Численні дослідження з годівлі дійної худоби та ВРХ на відгодівлі показали, що шрот позитивно впливає на кінцеву продукцію, не знижуючи ії якості $[4,5,6]$.

Виходячи з досвіду багаторічних досліджень умов праці в сільському господарстві можна вважати, що основними шкідливостями на технологічних етапах виробництва біопалива можуть бути : грунтовий пил, пестициди та пилок рослин на етапі вирощування рослин; пестициди, пил, бактеріальна та грибкова мікрофлора на етапі збирання врожаю; пари хімічних речовин, шум, органічний пил, мікрофлора при подрібненні та переробці сировини $[1,7,9,11]$.

Дослідження, що було проведено на різних сільськогосподарських підприємствах по переробці рослинної сировини показали, що дані забруднення повітря мікроорганізмами коливалися в широких межах від $1,0 \cdot 10^{3}$ до $1,0 \cdot 10^{9} \mathrm{KУO} / \mathrm{m}^{3}$ повітря. Ви- 
сокі концентрації мікроорганізмів спостерігали на тих ділянках, де здійснюється подрібнення та змішування, при ручному завантаженні компонентів $1,0 \cdot 10^{4}-1,0 \cdot 10^{8} \mathrm{KУO} / \mathrm{m}^{3}$. Всі ці операції супроводжувалися значним пиловиділенням, із перевищенням ГДК в десятки разів [9, 10, 17].

Результати дослідження по ідентифікації мікроорганізмів показали, що найбільш широко представлено аерогенні спорові мікроорганізми від 19,5 \% до 42 \% від загальної кількості мікроорганізмів, які відносяться до роду Bacillus.

Дослідження мікроскопічних грибів показали, що в процентному відношенні вони можуть переважати над кількістю бактерій. Їх концентрації знаходяться в межах від 25,0-50,0% від загальної кількості мікроорганізмів [11, 18].

Аналіз отриманих даних про мікробне забруднення виробничого середовища показав, що більше 50 \% мікроорганізмів відноситься до мікроскопічних грибів. Їхній вплив, зокрема, токсиноутворювання, має особливий аспект у переробці сільськогосподарської сировини. Багато авторів вказують на їх можливу роль у виникненні і розвитку респіраторних захворювань, імунодепресивній дії на клітинний і гуморальний імунітет, а також про підвищений ризик розвитку онкологічних захворювань у робітників, які зазнають впливу мікотоксинів у виробничому середовищі $[12,13,17]$.

3 даних літератури та власних досліджень відомо, що працівники, які зайняті на переробці рослинної сировини мають високий рівень частоти захворювань органів дихання. Це обумовлюється вПливом на організм виробничого пилу, що містить високі концентрації мікроорганізмів, їхні спори та токсини і чинить алергізуючу та сенсибілізуючу дію. Професійно-обумовленими можуть бути захворювання шкіри (контактні дерматози, грибкові захворювання шкіри), запальні захворювання переднього відділу ока (блефарокон'юктивіт та ін.). При впливі біологічного фактора порушується захиснобар'єрна функція слизових оболонок верхніх дихальних шляхів, ока і шкіри, що сприяє проникненню мікробних агентів в організм і призводить до розвитку запальних і інфекційних процесів. Крім того, є дані про наявність раку легенів і бронхів у групі робітників фабрики по виробництву рослин-

\section{Література}

1. Александров М. Микрофлора сена и соломы // Вет. мед. наук.- 1986.- № 4.- С. 61-65.

2. Біопалива (технологія, машини і обладнання) В.О.Дубровін, М.О.Корчемній та ін. К.:ЦТІ «Енергетика і електрифікація", 2004.- 256 с. ного масла, у робітників по переробці олійних культур були виявлені злоякісні пухлини різної локалізації, у тому числі і первинний рак печінки. Це пов'язано з наявністю мікотоксинів в сировині, яка перероблюеться в олію $[8,14,19]$.

Аналіз даних літератури та результатів наших попередніх досліджень свідчить про те, що на окремих технологічних етапах виробництва біопалива із рослинної сільськогосподарської сировини на працюючих можуть вПливати виробничі фактори різного походження, особливо біологічної природи. Подальші дослідження буде присвячено вивченню особливостей формування цих факторів, а також впливу на стан здоров’я працюючих та розробці комплексу санітарно-гігієнічних та профілактичних заходів.

\section{Висновки}

1. Проблема виробництва біопалива із рослинної сировини на близьку перспективу є для України надзвичайно актуальною та потребує свого вирішення у ближчий час.

2. Встановлено, що найбільш перспективною культурою щодо виробництва біопалива в УКраїні є ріпак. Це вже призводить до значного збільшення посівних площ під ріпак, а також залучення до технологічного процесу значної кількості працюючих.

3. Аналіз даних наукової літератури свідчить про те, що при вирощуванні ріпака використовуються різноманітні технологічні схеми застосування великого спектра пестицидів, літніх та озимих сортів ріпака, різні технічні засоби.

4. Під час вирощування ріпака та підготовки його до переробки на біопаливо на працюючих може впливати комплекс виробничих факторів: шум, вібрація, несприятливий мікроклімат, пестициди та інші засоби обробки рослин, багатокомпонентний пил, мікрофлора.

5. Біологічні чинники, що знаходяться у виробничому середовищі при виробництві біопалива із рослинної сировини можуть негативно впливати на стан здоров’я працюючих. Це може проявлятися високим рівнем частоти захворювань органів дихання, ризиком виникнення онкологічних захворювань, що обумовлюеться впливом на організм виробничого пилу та токсиноутворюючих мікроорганізмів.

3. Вірьовка М.І. Фізико-хімічні властивості альтернативного пального на основі рослинних олій // Механізація та електрифікація сільського господарства.- 2002.- Вип.86.- С 290-294.

4. Дубровін В.О. Розвиток технологій використання рослинницької продукції на енергетичні потреби в 
Україні // Аграрна наука і освіта.- 2004.- Т. 5.№ 1-2.- C.86-91.

5. Ковтун Г.О. Альтернативні моторні палива // Вісник НАН України,2005.- № 2.- С. 19-27

6. Кухар В.П., Кузьмінський Є.В., Гнатюк О.А., Голуб Н.Б. Екобіотехнологія та біоенергетика: проблеми становлення і розвитку // Вісник НАН України.2005. № 9.- C.3-18.

7. Bioaerosols Handbook (Red.C.S.Cox, C.M.Wathes). CRC Press, Boca Raton 1995. Causative Agents for Organic Dust Related Disease (Red.R.Rylander, Y.Peterson) // Am. J. Ind. Med.- 1994.- № 25.- P. 1-146.

8. Cosentino S., Palmas F. Assessment of airborne fungal spores in different industrial working environments // Envir. Monitoring \& Assess.- 1991.- V.16.№ 2.- P. 127-136.

9. Crook B., Olonchock S.A. Industrial workplaces. In: Cox CS, Wathes CM (Eds): Bioaerosols Handbook.1995.- P. 531-545.

10. Dutkiewicz J. Bacteria and fungi in organic dust as a potential health hazard // Ann. Agric. Environ. Med.- 1997.- № 4.- P. 11-16.

11. Dutkiewicz J. Microbial hazards in plants processing grain \& herbs // Am. J. Ind. Med.- 1989.- № 10.P. 300-302.

12. Golec M., Skorska C., Mackiewicz B., Dutkiewicz J. Immunologic reactivity to work-related airborne allergens in people occupationally exposed to dust from herbs environment // Ann Agric Environ.- Med.- 2004.- V.1.№ 1.- P.121-129.

13. Hendry K.M., Cole E.C. A reviev of mycotoxins in indoor air // J. of Toxicol. \& Evir. Health.- 1993.- V. 38.№ 2.- P. 183-198.

14. Lacey J., Dutkiewicz J. Bioaerosols and occupational lung disease // J. Aerosol Sciense.- 1994.- V.25.№ 8.- P. 1371-1404.

15. Lichts F.O. European Biodiesel Board Welcomes EU Biofuel Directive // World Ethanol and Biofuels Report.- 2003.- V. 1.- № 17.- P. 337.

16. Madsen A, Martensson L, Schaider T, Larsson L: Microbial dustiness and particle release of different biofuels // Ann. Occup. Hyg.- 2004.- № 48.- P. 327-338.

17. Madsen A. Exposure to airborne microorganisms, endotoxins and dust during work at biofuel plants. In: Appropriate Environmental and Solid waste Management and Technologies for Developing Countries.- 2002.- № 5.- P. 2719-2726

18. Radon K., Danuser B., Iversen M. at al. Air contaminants in different European farming environments environment // Ann agric Environ. Med.- 2002.- V. 9.№ 1.- P.41-48.

19. Sebastian A., Madsen A, Martensson L, Pomorska D., Larsson L. Assessment of microbial exposure risks from handling of biofuel wood chips and straw- effect of outdoor storage // Ann Agric Environ. Med.- 2006.V. 13.- № 1.- P.139-145.

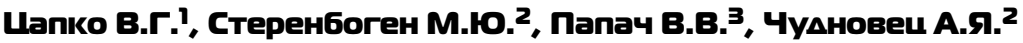 ГИГИЕНИЧЕСКИЕ АСПЕКТЫ ПРОИВВОАСТВА БИОТОПАИВА ИВ РАСТИТЕАЬНОГО СЕАЬСКОХОзЯЙСТвЕННОГО СЫРЬЯ (OБВОР)
}

\author{
'Национальный аграрный университет, г. Киев \\ 2ГУ «Институт меАицины труда АМН Украины», г. Киев \\ зобластная СЭС, г. Черкассы
}

Представлены данные анализа литературы и результаты исследований условий труда при производстве биотоплива из растительного сельскохозяйственного сырья на разных технологических этапах. Дана характеристика технологических и гигиенических особенностей производства биотоплива.

Ключевые слова: технологии производства, биотопливо, условия труда

\section{Tsapko V.G.', Sterenbogen M.Yu. ${ }^{2}$, Papach V.V.3, Chudnovets A.Y. ${ }^{2}$ HYGIENIC ASPECTS OF BIOFUEL PRODUCTION FROM AGRICULTURAL PLANT RAW MATERIAL (REVIEW)}

'National Agrarian University, Kiev

2Institute for Occupational Health of AMS of Ukraine, Kiev

${ }^{3}$ Regional SES, Cherkassy

The results of literature data analysis and those of hygienic studies of work conditions in production of power-producing plants at different technological stages are given. Technological and hygienic peculiarities of biofuel production have been estomated.

Key words: biofuel, work conditions, fuel production

Надійшла: 15.01.2009

Контактна особа: Стеренбоген Марина Юріївна, к.м.н., с.н.с. групи з вивчення біологічних факторів виробничого середовища, ДУ «Інститут медицини праці АМН України», 75, вул. Саксаганського, м. Київ. 